\title{
The English Learning Management in Primary School
}

\author{
Slamet Lestari \\ Educational Administration Department, \\ Education Science Faculty, Yogyakarta State University (UNY) \\ Yogyakarta, Indonesia \\ slamet_lestari@uny.ac.id
}

\begin{abstract}
The purpose of this research was to describe the English learning management, the problems of English learning management, and the attempt to overcome the problems of English learning management in State Primary School. This research was descriptive research. The research subject was English teachers in State Primary Schools in Gondokusuman sub-district, Yogyakarta. The data was collected by employing questionnaire, observation, and documentation. The data was analyzed by using percentage technique. The result of the research showed that: 1) The English learning management in Gondokusuman State Primary School was categorized as good. However, there were still some aspects that needed to be improved such educator quality, facility sufficiency, and fund to improve the quality of English learning. 2) Problems in English learning management in Gondokusuman State Primary School covered problems concerning students and facility. 3) The attempts to overcome the problems were to guide and build motivation by using learning method which is suitable with learning material and can motivate the students and to complete education facility.
\end{abstract}

Keywords-English, learning management

\section{INTRODUCTION}

Basic Education Curriculum which is adjusted to match regency condition and need of surrounding environment is established by Head of Regional Office of Education and Culture Department [1]. The background idea of Local Content Curriculum (here in after referred to as "LCC") is the fact that there are many students who dropped out or primary school graduate who did not continue their education to the next level due to financial problem or low intellectual competence. The high rate of dropout can cause high rate of unemployment as well.

By implementing LCC, the dropouts or primary school graduate who did not continue their education to the next level will have skill that they can use to make living. They are expected to be able to utilize potency which they can find in their surrounding environment. The implementation of LCC in one region differs with implementation of LCC in another region because one region has condition which differs with condition in another region. LCC is implemented to preserve and develop a culture in a regency and students are expected to be closer with the environment.

Certain local content subject can be applied in certain school according to the environment where study material of the subject is identified. Therefore, there are the terms 'compulsory local content subject' and 'optional local content subject'. LCC in Primary Schools in Gondokusuman Sub-district consists of compulsory LCC subject such as Bahasa Daerah (Regional Language) and optional LCC subjects that covers karawitan, agriculture, plaiting, making batik, carving, PKK, automotive, and English. As mentioned above, LCC implementation is adjusted to match condition of pertinent region. The optional LCC for Primary Schools in Gondokusuman Sub-district, Yogyakarta is English since Yogyakarta is a tourism city. It is a good choice since students who cannot continue their education to the next level are expected to be able to utilize English to make their own living or to help their family.

English in LCC is implemented from grade IV to grade VI. The duration of this LCC can be adjusted according to available duration, condition, and need of the environment. The implementation of English learning needs competent English teacher. This is one problem in implementation of English learning. In addition, another problem is insufficiency of tools that support implementation of English learning.

One of indicators of successful English learning implementation in Primary School is good management. This good management covers planning, executing, and evaluating concerning pertinent local content subject. However, in fact, most teachers have not been understood the advantage of this management. From the elaboration above, it can be concluded that LCC implementation still faces problems. This case happens because English subject in Primary School is still something new. Therefore, the researcher wanted to try to dig and research the English learning management in State Primary Schools in Gondokusuman sub-district, Yogyakarta. Specifically, the purpose of this research are as follows: 1) To find out the English learning management in State Primary Schools in Gondokusuman sub-district, Yogyakarta. 2) To find out the problems and solutions concerning English learning 
management in State Primary Schools in Gondokusuman sub-district, Yogyakarta.

Managing is an action that covers arranging data, organizing, executing, supervising, and assessing [2]. It is also explained that the result of management can be consummation or improvement of the next management. In general, the function of management covers planning function, executing function, and assessing function. Planning function is the first function of the entire management function which is often mentioned by experts. Every activity program needs a planning because with planning, the activity can achieve its goal effectively and efficiently. Executing function is the main function of the whole activity. In fact, if an activity is not executed, the purpose of the activity cannot be achieved and the activity will fail. Assessing function is defined as a process to monitor an activity. This process is employed to find out whether the related individual or organization get and use the resources effectively and efficiently to achieve the goal of the activity. In addition, betterment activity can be executed if it is necessary.

LCC is a learning plan whose study material and subject are taken from or adjusted to suit the condition of local environment and the need of regional development [2]. National Education Department states that the purpose of LCC is to make students to be able: 1) to get close and be familiar with their environment, 2) to know more about their environment and to respect environment or socio-culture in their environment, 3) to improve their knowledge about their region, 4) to decide knowledge and skill that they study and to solve problems that they find in their surroundings, and 5) to support their parents and to help themselves to fulfill their need [3]. The term "local" means region scope where the study material is implemented. The scope of local content covers: 1) regional culture education which covers regional language, regional arts, custom, regional sport, etc. 2) skill education which covers regional skill, handicraft skill, etc. 3) environment education which covers insight concerning education environment, character, etc [2].

Basically, language is a tool to convey idea, mind, opinion, and feeling. English is the first foreign language in Indonesia which is considered to be important for the purpose of absorption and development of science, technology, and cultural arts and the purpose to build relation with other nations. English subject is local content subject in Primary School which is intended to introduce English as first foreign language to students. The purpose of English teaching in Primary School is to motivate and push students to be ready and confident in learning English in the next level. English teaching in Primary School covers pronunciation, vocabulary of writing, reading, and functional skill as a base to get simple language skill according to topic which is familiar for students including tourism topic. So, the meaning of English learning covers planning, executing, assessing of English learning, problems,and solution concerning English learning management.

\section{METHOD}

This research was descriptive research. This research was conducted at State Primary Schools in Gondokusuman sub-district, Yogyakarta in August - October 2009. This research was categorized as population research since the researcher took data from all population subjects. There were 13 English teachers who were involved in this research (each Primary School in Gondokusuman sub-district has 1 English teacher). The data was collected by employing questionnaire, observation, and documentation study. The questionnaires which were used were open questionnaire and closed questionnaire. Closed questionnaire was used to figure out the implementation of English learning. Open questionnaire was used to figure out problems and solutions concerning implementation of English learning. Observation method was employed to research the process of English learning and documentation method was used to collect documents concerning English learning management. The technique of data analysis in this research was descriptive technique.

\section{DISCUSSION}

This research was conducted in Gondokusuman subdistrict, Yogyakarta which had 13 State Primary Schools. All schools in Gondokusuman sub-district had implemented both compulsory LCC and optional LCC. Optional LCC covers some subjects such as dance art, Karawitan art, plaiting, English, etc. To implement of English learning in State Primary Schools in Gondokusumansub-district, outsider teachers who could teach English were taken.

There were some ways which were used by school to get English teacher. These ways are presented in the following table.

Table 1. The Way Schools Get English Teacher

\begin{tabular}{llc}
\hline No & The Way Schools Get English Teacher & $\%$ \\
\hline 1. & Placed by the Education Department & 23 \\
2. & Applying to Schools & 54 \\
3. & Asked by the Schools & 23 \\
4. & Others & 0 \\
\hline Total & & 100 \\
\hline
\end{tabular}

From the table above, it was found that most English teachers in Primary Schools in Gondokusuman sub-district (54\%) became English teachers by applying to the schools. 
Schools announced the job vacancy of English teachers and listed its qualification. Then, the schools conducted selection towards those who applied. The candidate who met the qualification would be hired by the schools.

English teachers had various education backgrounds. The following table shows the education background of English teachers in Primary Schools in Gondokusuman subdistrict, Yogyakarta.

Table 2. Education Background of English Teachers

\begin{tabular}{llc}
\hline No & Education Background of English Teachers & $\%$ \\
\hline 1. & Bachelor's degree of English & 46 \\
2. & Associate's degree of English (Diploma 3) & 23 \\
3. & Associate's degree of English (Diploma 2) & 15 \\
$4 . \quad$ Others & 15 \\
\hline Total & & 100 \\
\hline
\end{tabular}

It was found that the background education of most English teachers in Primary Schools in Gondokusuman subdistrict $(46 \%)$ was bachelor's degree of English Education. It meant that employment of teachers had been suitable with the principle "the right man on the right place."

\section{The English Learning Management}

The activity of curriculum planning covers syllabi arrangement, subject unit, and subject material analysis. This activity is conducted routinely by teachers in the beginning of a semester. This activity is intended to prepare learning material or supporting aspects in learning process such as text book, visual aid, strategy, or learning method that will be used. The result of the research concerning the planning of English in Primary Schools in Gondokusuman sub-district is presented in the following table.

Table 3. Planning of English Learning

\begin{tabular}{lccccc}
\hline $\begin{array}{c}\text { Planning of } \\
\text { English } \\
\text { Learning }\end{array}$ & $\begin{array}{c}\text { Never } \\
(\%)\end{array}$ & $\begin{array}{c}\text { Seldom } \\
(\%)\end{array}$ & $\begin{array}{c}\text { Often } \\
(\%)\end{array}$ & $\begin{array}{c}\text { Always } \\
(\%)\end{array}$ & Score \\
\hline $\begin{array}{l}\text { Arranging of } \\
\text { Syllabi }\end{array}$ & 0 & 0 & 13 & 87 & 96 \\
\hline $\begin{array}{l}\text { Arranging of } \\
\text { Subject Unit }\end{array}$ & 0 & 0 & 13 & 87 & 96 \\
\hline $\begin{array}{l}\text { Arranging of } \\
\text { Subject Matter } \\
\text { Analysis }\end{array}$ & 0 & 17 & 53 & 30 & 71 \\
\hline Mean & & & & & \\
\hline
\end{tabular}

From the table above, it was found that the planning of English learning in Primary Schools in Gondokusuman sub-district was categorized as good and the mean score was 88. Arranging syllabi is a part of routine which was conducted by English teachers in State Primary Schools in Gondokusuman sub-district. They arranged the syllabi individually and as a group through Subject Teacher Consultation. The aspect that needed to be improved was aspect concerning teachers' activity in arranging learning material. This activity covers activity of elaborating and developing learning material which can be taken from Outline of the Teaching Program, guide book from City Education Department, or students' text book.

Curriculum execution is the implementation of matters that have been planned before (at the beginning of semester of before entering class room). Curriculum execution is also "the real teaching." "The real teaching" means the real teaching at class according to lesson schedule (intra-curricular). The activity of curriculum execution covers opening lesson, presenting learning material, using learning resource, using learning method, using teaching media, and managing class. The research result concerning execution of English learning in Primary Schools in Gondokusuman sub-district is presented in the following table.

Table 4. Execution of English Learning

\begin{tabular}{lccccc}
\hline $\begin{array}{c}\text { Execution of } \\
\text { English } \\
\text { Learning }\end{array}$ & $\begin{array}{c}\text { Never } \\
(\%)\end{array}$ & $\begin{array}{c}\text { Seldom } \\
(\%)\end{array}$ & $\begin{array}{c}\text { Often } \\
(\%)\end{array}$ & $\begin{array}{c}\text { Always } \\
(\%)\end{array}$ & Score \\
\hline $\begin{array}{l}\text { Managing } \\
\text { learning resource }\end{array}$ & 0 & 0 & 37 & 63 & 88 \\
\hline $\begin{array}{l}\text { Managing } \\
\text { teaching method }\end{array}$ & 0 & 10 & 30 & 60 & 83 \\
\hline $\begin{array}{l}\text { Managing } \\
\text { Teaching Media }\end{array}$ & 0 & 20 & 7 & 73 & 84 \\
\hline Managing Class & 0 & 0 & 37 & 57 & 82 \\
\hline Mean & & & & & 84 \\
\hline
\end{tabular}

As presented in table above, it was found that in general, the execution of English learning in State Primary Schools in Gondokusuman sub-district was categorized as good and the mean score was 84. Specifically, there were some aspects that needed to be preserved or improved such as 1) availability of learning resource (lesson book and supporting book), 2)the use of learning method which was interesting, had more variation, and could motivate students to learn English, 3) the availability of learning facilities such as (a) learning tools, (b) simple learning media (board and chalk) or sophisticated learning media (OHP, LCD, desktop computer, and laptop) and therefore can clear material and 
add learning motivation, and (c) visual aids such as picture, audio cassette, video, and recorder tape, and 4) teachers' ability in managing class (class control to make students stay focused on learning process).

The activity of curriculum assessment in this research covered: 1) evaluation of students' learning result, 2) evaluation of the use of learning method, and 3) evaluation of the use of learning facilities. The following table shows the result of this research.

Table 5. Evaluation of English Learning

\begin{tabular}{lccccc}
\hline $\begin{array}{l}\text { Evaluation } \\
\text { of English } \\
\text { Learning }\end{array}$ & $\begin{array}{c}\text { Never } \\
(\%)\end{array}$ & $\begin{array}{c}\text { Seldom } \\
(\%)\end{array}$ & $\begin{array}{c}\text { Often } \\
(\%)\end{array}$ & $\begin{array}{c}\text { Always } \\
(\%)\end{array}$ & Score \\
\hline $\begin{array}{l}\text { Evaluation } \\
\text { of Learning } \\
\text { Result }\end{array}$ & 0 & 0 & 37 & 37 & 37 \\
\hline $\begin{array}{l}\text { Evaluation } \\
\text { of Learning } \\
\text { Method }\end{array}$ & 0 & 8 & 15 & 15 & 15 \\
\hline $\begin{array}{l}\text { Evaluation } \\
\text { of Learning }\end{array}$ & 0 & 70 & 15 & 15 & 15 \\
Facility & & & & & \\
\hline Mean & & & & & \\
\hline
\end{tabular}

In general, the evaluation of English learning in State Primary Schools in Gondokusuman sub-district was categorized as good and the mean score was 86. Evaluation of the use of teaching method needed to be conducted in order that the teaching method that had been used could be improved or perfected. Therefore, the teaching method can be used to teach English effectively according to material and students' characteristic. From the table above, it was found that $77 \%$ of English teachers in State Primary Schools in Gondokusuman sub-district always evaluate their teaching method. It was also found that $15 \%$ of those teachers often evaluate their teaching method and the rest (8\%) seldom conduct evaluation concerning their teaching method.

From the table above, it was also found that $15 \%$ of teachers always evaluated learning facilities, $15 \%$ of teachers often evaluated learning facilities, and $70 \%$ of teachers seldom evaluate learning facilities. This case happened because learning facilities, especially visual aid and learning media, were not sufficient. Due to this case, schools needed to improve English teachers' creativity in making learning media and simple visual aid. Therefore, English learning can be effective.
Problems and Solutions Concerning of English Learning Management

It was found that the English learning management in State Primary Schools in Gondokusuman sub-district faced some problems. The researcher categorized the problems into two groups. The first were problems concerning students' condition such as perseverance, ability, disciplinary, learning motivation, etc. The second were problems concerning the condition of learning facility such as availability of rooms, lesson kits/supporting book, learning media, and visual aid (picture, audio cassette, video, etc.).

Table 6. Problems concerning students

\begin{tabular}{llc}
\hline No & \multicolumn{1}{c}{ Problems Concerning Students } & $\%$ \\
\hline 1. & Perseverance & 23 \\
2. & Ability & 31 \\
3. & Learning Motivation & 31 \\
4. & Interest & 15 \\
\hline \multicolumn{2}{l}{ Total } & 100 \\
\hline
\end{tabular}

The table above showed that the problems of English learning in State Primary Schools in Gondokusuman subdistrict which came from students were different ability of each student (31\%), low students' motivation (31\%), perseverance which was reflected upon lazy students $(23 \%)$, and low students' interest in English (12\%).

Table 7. Problems concerning learning facility

\begin{tabular}{clc}
\hline No & Problems Concerning Learning Facility & $\%$ \\
\hline 1. & Lesson Kits & 54 \\
2. & Visual Aid & 23 \\
3. & Learning Media & 15 \\
4. & English Laboratory & 8 \\
\hline \multicolumn{2}{r}{ Total } & 100 \\
\hline
\end{tabular}

The table above showed that problems concerning learning facility covered lesson kits (54\%), visual aid (23\%), learning media, and English laboratory (8\%).

There were various attempts to overcome problems concerning English learning management in in State Primary Schools in Gondokusuman sub-district. These attempts are as follows:

1. Teachers made summary from learning material and handedit to students. 
2. Referring to LCC guidance and supporting book.

3. Completing students' handbook.

4. Making material which is adjusted to match students' ability.

5. Making book and learning media.

6. Giving a lot of exercise to students.

7. Proposing fund to school or department to add facility to support English learning.

8. Sharing ideas with English teacher from another school.

9. Adding supporting book and proposing fund in School Budget and Revenue Plan.

10. Setting English reading and writing exercise and setting homework.

11. Providing guidance concerning how to do English task.

12. Starting and ending English lesson on time.

\section{CONCLUSION}

The conclusions that can be derived from research result and discussion above are as follows.

1. The English learning management in Gondokusuman State Primary School was categorized as good. However, there were still aspects that needed to be improved such as educator quality, facility, and fund to develop English learning quality.

2. Problems in English learning management in Gondokusuman State Primary School covered problems concerning students and facility.

3. The attempts to overcome the problems concerning English learning management in Gondokusuman State Primary School are as follows: a) guiding and building motivation by using learning method which is suitable with learning material and can motivate the students and b) completing education facility.

\section{REFERENCE}

[1] Decree of the Minister of Education and Culture Number 060/U/1993 concerning Basic Education Curriculum.

[2] Arikunto, Suharsimi. 2000. Manajemen Kurikulum. Yogyakarta: Jurusan Administrasi Pendidikan FIP UNY.

[3] National Education Department of Republic Indonesia. 2003. Standar Kompetensi Bahan Kajian: Pelayanan Profesional Kurikulum Berbasis Kompetensi. Jakarta: Centre Curriculum of Research and Development Centre. 